\title{
IAMJ
}

INTERNATIONAL AYURVEDIC MEDICAL JOURNAL

\section{A CLINICAL STUDY OF SHILAJEET VATI IN PRAMEHA PURVARUPA (PRE-DIABETIC STATE)}

\author{
Esha Dhiman ${ }^{1}$, Neetu Jha ${ }^{2}$, Pradip Kumar Panda ${ }^{3}$, Utkalini Nayak ${ }^{4}$, Vinod Chandra Singh ${ }^{5}$ \\ ${ }^{1}$ PG Scholar, P.G. Department of Roga Nidana Evum Vikriti Vigyana \\ ${ }^{2}$ PG Scholar, P.G. Department of Samhita \& Siddhanta \\ ${ }^{3}$ Dean, Sri Sri College of Ayurveda Science and Research Hospital Sri Sri University, Cuttuck \\ ${ }^{4}$ Reader and HOD, P.G. Department of Roga Nidana Evum Vikriti Vigyana \\ ${ }^{5}$ Lecturer, P.G. Department of Roga Nidana Evum Vikriti Vigyana \\ Govt. Ayurvedic College \& Hospital, Balangir, Odisha, India
}

Corresponding Author: dr.eshatomar@gmail.com

https://doi.org/10.46607/iamj0409112021

(Published Online: November 2021)

Open Access

(C) International Ayurvedic Medical Journal, India

Article Received: 06/10//2021 - Peer Reviewed: 27/10/2021 - Accepted for Publication: 31/10/2021

\section{Check for updates}

\section{ABSTRACT}

Introduction- The incidence of Prameha is increasing rapidly because of changes in dietetic habits and lifestyle. If the Prameha Purvarupa (Pre-diabetic) clinical features are treated by formulation Shilajeet is recommended in Ayurvedic Classics, proven efficacious and widely practised in the management of Prameha (Diabetes). Materials and methods- 30 patients from OPD and IPD of Govt. Ayurvedic College \& Hospital, Balangir, fulfilling the Subjective and Objective Parameters were registered for the clinical trial. After diagnosis, they were under trial with Ayurvedic formulation Shilajeet Vati treated in a dose of 2 Vati (500mg each) twice daily empty stomach, for a period of 30 days with Ushna Jala. The assessment of subjective and objective parameters was evaluated on the $10^{\text {th }}, 20^{\text {th }}$ and 30th day from the day of initiation of trial up to 30 days in order to find the efficacy of the trial by statistical paired ' $t$ ' test. Observation and results- The average percentage of improvement in subjective parameter Prabhuta Mutrata (quantity) 71.43\%, Prabhuta Mutrata (frequency) 77.78\%, Pipasa (increased thirst) 72.73\%, Kshudha (excessive appetite) $72.22 \%$, Kara-pada Daha (burning sensation in hand and feet) $73.81 \%$, 
Kara-pada Suptata (numbness of hand and feet) 80\%, Sweda Pravritti (excessive sweating) 83.33\%, Mukha Shosha (dry mouth) $79.17 \%$, Mukha Madhurya (sweetness in mouth) $77.78 \%$, Sheeta Priyata (liking for cold things) $80 \%$ and Madhura Shukla Mutrata (sweetness in urine) $100 \%$ and in objective Parameter fasting plasma glucose $68.89 \%$, postprandial glucose $81.11 \%$, HbA1c $73.33 \%$. It has been observed that the trial drug patients are highly significant $(\mathrm{p}<0.001)$ to reduce both Subjective and Objective parameters after 30 days of treatment. Discussion and Conclusion- Prameha is a Kapha Pradhana Tridoshaja Vyadhi in which Meda is a Pradhana Dushya. The drug showed a potent Pramehahar effect which is evident from the reduction in the Subjective Parameter of Prameha and objective parameter of the levels of FBS, PPBS and HbA1c in patients. No side effect was noticed during the clinical study of Shilajeet Vati.

Keywords: Prameha, Diabetes, Shilajeet Vati.

\section{INTRODUCTION}

In Ayurveda, Prameha is described as a set of complex clinical disorders characterized by excessive urination (both in frequency and quantity), and turbidity $^{1}$. The nature of the turbidity may vary depending upon the body reacts to the doshas ${ }^{2}$. Nowadays the disease Prameha has evolved as a life complicating disorder. Prameha is a Tridoshajanya Vikara due to the simultaneous vitiation of all the three Doshas ${ }^{3}$. Ayurveda describes 20 types of Prameha as different clinicopathological conditions produced out of specific Doshas and Dushyas, showing gross urinary characteristics and clinical manifestations. The fractional changes in Dushyas namely Meda, Mamsa, Kleda, Shukara, Shonita, Vasa, Majja, Lasika, Rasa and Oja, in association with three morbid Doshas manifests different subtypes of Prameha ${ }^{4}$. Shilajeet is one such drug the use of which has been advocated for Prameha in ancient texts 5 . So, for better and safe treatment Ayurvedic preparation Shilajeet Vati are selected for the present research protocol in Prameha. AIM AND OBJECTIVE OF THE STUDY

1. To study the efficacy of Shilajeet vati in the management of Prameha.

2. To find out a suitable herbal drug for the treatment of Prameha.

3. To correlate Prameha in modern parlance.

\section{MATERIALS AND METHODS}

\section{Selection of Patients}

A total of 30 patients had been selected by special proforma covering demography along with both Subjective and Objective parameters from OPD and IPD of Govt. Ayurvedic College and Hospital, Balangir and Saradeshweri Govt. Ayurvedic Hospital Balang$i r$. The consent of patients was also taken before the clinical trial.

\section{Inclusion Criteria}

Patients aged between 30-65 years of both sexes. Patients having symptoms of Prabhuta Mutrata (frequency of micturition), Pipasa (increased thirst), Kshudha (excessive appetite), Kara-pada Daha (burning sensation in hand and feet), Kara-pada Suptata (numbness of handand feet), Sweda Pravritti (excessive sweating), Mukha Shosha (dry mouth), Mukha Madhurya (sweetness in mouth), Sheeta Priyata (liking for cold things) Madhura Shukla Mutrata (sweetness in urine). Patients having FBS (100$125 \mathrm{mg} \%)$, PPBS (140-200mg\%) and HbA1c (5.7$6.4 \mathrm{mg} / \mathrm{dl}$ ) were selected for this study.

\section{Exclusion Criteria}

Patients age $<30$ years and $>65$ years, fasting plasma glucose $>125 \mathrm{mg}$, oral glucose tolerance $>200 \mathrm{mg} \%$, HbA1c $6.5 \%$ or more, having complications of diabetes like ketoacidosis, nephropathy, neuropathy, retinopathy, and diabetic wounds, chronic, contagious infection diseasesuch as active tuberculosis, hepatitis B or C, or HIV, Pregnant and lactating females, active metabolic or gastrointestinal disease that may interfere with nutrient absorption, metabolism, excretion, excluding diabetes, Type- 1 diabetes mellitus and Type-2 diabetes mellitus. 


\section{Criteria for Investigations}

$\mathrm{Hb} \%$, TLC, DLC, Urine (Routine and Microscopic), Fasting blood sugar (FBS), Postprandial blood sugar (PPBS), HbA1c were investigated initially and follow up periods.

\section{Selection of Drug}

Shilajeet Vati had been taken for the clinical trial. The drug was identified by the experts of Dept. of Dravyaguna and Rasashastra and Bhisajya Kalpana which were approved by DRC and IEC of College and Sambalpur University. Medicines were prepared as per GMP certified method in Mini Pharmacy of College under the supervision of experts of Rasashastra and Bhisajya Kalpana.

\section{Method of preparation of Shilajeet Vati}

Good quality and given proportion of Shilajeet was added to prepared Triphala Kwatha and then filtered with a cotton cloth. The final filtrate Shilajeet was taken in a stainless-steel vessel (kadhai) placed over a mild fire, boiled, and reduced to a thicker consistency. Vati of $500 \mathrm{mg}$ was made with the help of Goghrita and dried packed as per recommended dose.

\section{Administration of Drug}

The trial drug Shuddha Shilajeet was given by oral route in the dose of 2 vati (500mg each) twice daily empty stomach, for a period of 30 days with Ushna Jala.

Table 1: Showing the pharmacodynamics of drug of Shilajeet Vati

\begin{tabular}{|c|c|c|c|c|c|c|}
\hline Name & Rasa & Guna & Veerya & Vipaka & Doshakarmata & Quantity \\
\hline Shilajeet & Tikta Lavana & SheetaGuru Snigdha & Sheeta & Katu & Tridoshashamaka & $950 \mathrm{gm}$ \\
\hline \multicolumn{7}{|c|}{ Triphala Kwatha } \\
\hline Haritaki & $\begin{array}{l}\text { Kasaya, Madhura, Am- } \\
\text { la, Katu, Tikta (Pan- } \\
\text { charas) }\end{array}$ & Laghu, Ruksha & Ushna & Madhura & Tridoshashamaka & $315 \mathrm{gm}$ \\
\hline Bibhitaki & Kasaya & Ruksha, Laghu & Ushna & Madhura & Tridoshashamaka & $315 \mathrm{gm}$ \\
\hline Amalaki & $\begin{array}{l}\text { Amlapradhana Lavana } \\
\text { Varjita Pancharasa }\end{array}$ & Guru, Laghu, Sheeta & Sheeta & Madhura & Tridoshashamaka & $315 \mathrm{gm}$ \\
\hline
\end{tabular}

Assessment Criteria: The Subjective parameters and Objective parameters as per Inclusion Criteria were assessed by the grading score from 0 to 3 according to the severity of disease and favourable shift to back. Both parameter follow-ups were taken on the $10^{\text {th }}, 20^{\text {th }}$ and $30^{\text {th }}$ day of medication. The overall assessments were done considering the percentage re- lief of both parameters and statistical evaluation. OBSERVATION AND RESULT

Within the aforesaid period, the demography (Table No.-02) based on Age-Sex-Religion etc. along with the incidence of Dashvidha Pariksha (Table No.-03) were observed and assessed.

Table 2: Demography Incidence of Registered Patients. $(n=30)$

\begin{tabular}{|l|l|l|}
\hline Criteria & Maximum Percentage & Category \\
\hline Age & $53.33 \%$ & $40-50$ years \\
\hline Sex & $53.33 \%$ & Male \\
\hline Religion & $100 \%$ & Hindu \\
\hline Education status & $73.33 \%$ & Literate \\
\hline Occupation & $53.33 \%$ & Service \\
\hline Socio- Economical status & $73.33 \%$ & Middle class \\
\hline Marital status & $100 \%$ & Married \\
\hline Dietary habit & $80 \%$ & Mixed diet \\
\hline Habit / Addiction & $70 \%$ & Taking tea \\
\hline
\end{tabular}




\begin{tabular}{|l|l|l|}
\hline Mode of onset & $100 \%$ & Gradual \\
\hline History of past illness & $60 \%$ & No past history \\
\hline Family history & $60 \%$ & Absent \\
\hline Sleeping habit & $66.66 \%$ & Less sleep \\
\hline Urination & $60 \%$ & More \\
\hline Bowel habit & $53.33 \%$ & Normal \\
\hline
\end{tabular}

Table 3: Incidence of Dashavidha- Pariksha of Registered Patients. ( $\mathrm{n}=30)$

\begin{tabular}{|l|l|l|}
\hline Criteria & Maximum Percentage & Category \\
\hline Prakriti & $43.33 \%$ & Vatakapha \\
\hline Vikriti & $50 \%$ & Madhyama- vastha \\
\hline Sara & $63.33 \%$ & Madhyama-sara \\
\hline Samhanan & $53.33 \%$ & Madhyama \\
\hline Pramana & $86.67 \%$ & Madhyama sharira \\
\hline Satwa & $50 \%$ & Madhyama \\
\hline Satmya & $53.33 \%$ & Madhyama \\
\hline Ahara Shakti & $70 \%$ & Madhyama Ahara Shakti \\
\hline Vyayama Shakti & $63.33 \%$ & Hinabala Vyayama Shakti \\
\hline Vaya & $60 \%$ & Madhyamavastha \\
\hline
\end{tabular}

The Subjective and Objective Parameters of research patients were observed during the clinical study. The percentage of improvement was also observed and assessed after the clinical trial. (Table No.-04)

Table 4: Showing the observation of total patients as per disease and percentage of Improvement (n=30) (fFrequency, \%-Percentage)

\begin{tabular}{|c|c|c|c|}
\hline Symptoms & Frequency & Percentage & Percentage of Improvement \\
\hline \multicolumn{4}{|l|}{ Subjective Parameter } \\
\hline Prabhuta Mutrata (Quantity) & 7 & 46.67 & 71.43 \\
\hline Prabhuta Mutrata (Frequency) & 6 & 40 & 77.78 \\
\hline Pipasa (Increased thirst) & 11 & 73.33 & 72.73 \\
\hline Kshudha (Excessive appetite) & 9 & 60 & 72.22 \\
\hline Kar-pada Daha (Burning sensation in hand and feet) & 7 & 46.67 & 73.81 \\
\hline Kar-pada Suptata (Numbness in hand and feet) & 4 & 26.67 & 80 \\
\hline Sweda Pravriti (Excessive Sweating) & 7 & 46.67 & 83.33 \\
\hline Mukha Shosha (Dry mouth) & 8 & 53.33 & 79.17 \\
\hline Mukha Madhurya (Sweetness in mouth) & 6 & 40 & 77.78 \\
\hline Sheeta Priyata (Liking for cold things) & 5 & 33.33 & 80 \\
\hline Madhura Shukla Mutrata (Sweetness and whitish in urine) & 3 & 20 & 100 \\
\hline \multicolumn{4}{|l|}{ Objective Parameter } \\
\hline FBS & 30 & 100 & 68.89 \\
\hline PPBS & 30 & 100 & 81.11 \\
\hline $\mathrm{HbA1c}$ & 30 & 100 & 73.33 \\
\hline
\end{tabular}

After observation of subjective and Objective Parameters, the statistical analysis of parameters was assessed with help of statistical methods. (Table No.-05) 
Table 5: Showing the Statistical Analysis of Subjective Parameter and ObjectiveParameter. $(n=30)$

\begin{tabular}{|c|c|c|c|c|}
\hline \multirow[t]{2}{*}{ Symptoms } & \multicolumn{2}{|l|}{ Mean \pm SD } & \multirow[t]{2}{*}{ value } & \multirow[t]{2}{*}{ p-value } \\
\hline & Before treatment & After treatment & & \\
\hline \multicolumn{5}{|l|}{ Subjective parameter } \\
\hline $\begin{array}{l}\text { PrabhutaMutrata } \\
\text { (Quantity) }\end{array}$ & $2.14 \pm 0.69$ & $0.71 \pm 0.76$ & 7.07 & $<0.001$ \\
\hline $\begin{array}{l}\text { Prabhuta Mutrata (Fre- } \\
\text { quency) }\end{array}$ & $2.50 \pm 0.84$ & $0.67 \pm 0.82$ & 5.97 & $<0.005$ \\
\hline Pipasa & $2.09 \pm 0.70$ & $0.55 \pm 0.52$ & 7.46 & $<0.001$ \\
\hline Kshudha & $2.11 \pm 0.78$ & $0.67 \pm 0.71$ & 5.96 & $<0.05$ \\
\hline Kara-padaDaha & $1.86 \pm 0.69$ & $0.57 \pm 0.53$ & 6.97 & $<0.001$ \\
\hline Kar-pada Suptata & $1.50 \pm 0.58$ & $0 \pm 0.00$ & 5.20 & $<0.05$ \\
\hline Sweda Pravriti & $1.86 \pm 0.69$ & $0.43 \pm 0.79$ & 7.07 & $<0.001$ \\
\hline Mukha Shosha & $2.00 \pm 0.76$ & $0.50 \pm 0.53$ & 7.94 & $<0.001$ \\
\hline Mukha Madhurya & $1.83 \pm 0.75$ & $0.33 \pm 0.52$ & 4.39 & $<0.01$ \\
\hline Sheeta Priyata & $1.60 \pm 0.55$ & $0.40 \pm 0.55$ & 6.00 & $<0.005$ \\
\hline Madhura ShuklaMutrata & $1.33 \pm 0.58$ & $0.0 \pm 0.0$ & 4.00 & $<0.05$ \\
\hline \multicolumn{5}{|l|}{ Objective Parameters } \\
\hline FBS & $2.87 \pm 0.35$ & $0.93 \pm 0.70$ & 12.61 & $<0.05$ \\
\hline PPBS & $2.20 \pm 0.68$ & $0.47 \pm 0.64$ & 9.54 & $<0.05$ \\
\hline HbA1c & $1.80 \pm 0.68$ & $0.60 \pm 0.74$ & 8.29 & $<0.05$ \\
\hline
\end{tabular}

S. $\mathrm{D}=$ standard deviation, $\mathrm{t}=$ test of significance, $\mathrm{p}=$ probability; $<0.05=$ significant at $5 \%$ level, $<0.01$ $=$ significant at $1 \%$ level, $<0.005=$ significant at $0.5 \%$, $<0.001=$ Highly significant at $0.1 \%$ level

\section{DISCUSSION}

The present study was undertaken to interpret the efficacy of Shilajeet Vati in the management of Prameha.

Regarding demographic incidence it has been observed that (Table No.-02) males of middle age group, educated residing in urban areas, middle class, married, mixed diet, addiction of taking tea and having more urination and less sleep were prone to Prameha. Individual Dashavidha- Pariksha was covered and observed that (Table No.-03) the VataKapha patients having Madhyama - Sara-Samhanan- Pramana- Satwa- Satmya- Ahara Shakti and Hinabala Vyayama Shakti were manifested with Prameha.

The effect of therapy was assessed on the basis of observations of subjective and objective parameters which was significant $(\mathrm{p}<0.05)$ statistically after 30 days. (Table No.-04 and 05). The outcome of the study showed ample evidence of Shilajeet Vati acting as Pramehahar and showed a significant result in reducing the symptoms. Shilajeet has Tikta, Katu, and Kashaya Rasa, Katu Vipaka, Ushna Virya, Rechaka, Shoshana and Chedana properties. It has Rasayana, Vrishya andPramehaghna properties also. The selected Rasayana drug showed better improvement on subjective and objective parameters. The Ayurveda inspired a holistic approach to have a unique response promoting Agni (bio fire) and Ojas (immune strength) status leading to good health and wellness. So, Shilajeet has Lavana Rasa which acts on Agni and maintains the excellent status of Agni. Katu Vipaka and Ushna Virya acts on Srotas and remove theblockage of microchannels leading to better perfusion of tissue. It reduces the quantity of Kapha, Meda and Kleda by its properties which are the Dushyas in Prameha. Rasayana property of Shilajeet nourishes the body, helps to keep the body tissue in a healthy state and improves the metabolism at each and every level of Dhatu. It can also function as an antioxidant to improve the body's immunity and memory, anti- 
inflammatory, and energy booster. Due to Rechaka property, it acts as a diuretic to remove excess fluid from the body. (Table No.-1)

\section{CONCLUSION}

In the present study, Shilajeet was evaluated for its efficacy in Prameha Purvarupa (Pre-diabetic Condition). The drug showed a potent Pramehahar effect which is evident from the reduction in fasting and postprandial blood glucose levels, glycosylated haemoglobin and improvement in subjective parameters including the quality of life, psychological and social well-being. So, the study revealed that Shilajeet Vati can be used as a drug in the management of Prameha Purvarupa. The present study was carried out with certain limitations like fewer samples. Forthcoming researchers may pursue further study in large sample size over a period of longer duration. No side effect was noticed during the clinical trial.

\section{ACKNOWLEDGEMENT}

I am very much grateful and thankful to Principal Prof. (Dr.) Arun Kumar Das, Dr G.B. Acharya, H.O.D Dravyaguna, Dr S.B. Behera, H.O.D Rasashastra \& Bhaisajya Kalpana, Dr Utkalini Nayak, Reader RNVV, Dr M.R Sahu, Lecturer, RNVV for their grateful blessings. I am also thankful to all my P.G. Scholars friends, Hospital Staff, and other Staff of RNVV dept. for their constant helping attitude to complete the research work with satisfaction and belief.

\section{REFERENCES}

1. Sushruta Samhita, "Ayurveda Tatwa Sandeepika" by Kaviraja Dr Ambikadutt Shastri, vol-1, EditionReprint-2014, Chapter-06, Nidanasthana Chaukhamba BharatiAcademy. Sloka 6/6 Page No.-326

2. Astangahrdayam, edited with "Vidyotini" Hindi commentary by Acharya Kaviraja Atrideva Gupta, Edition- Reprint- 2016, Chapter-10, Sloka 10/7 Nidansthana, Chaukhamba Sanskrit pratisthana Page No.-345

3. Charaka Samhita, "Vidyotinitika" vol-1, by Pandit Kashinatha Panday and Dr Gorakhnatha Chaturvedi, Edition-Reprint-2016, Chapter-06, Chikitsasthana,
Chaukhamba Bharati Academy.Page No.-229

4. Charaka Samhita, "Vidyotinitika" vol-1, by Pandit Kashinatha Panday and Dr Gorakhnatha Chaturvedi, Edition-Reprint-2016, Chapter-06, Chikitsasthana, Chaukhamba Bharati Academy.Page No.-229

5. Sushruta Samhita, "Ayurveda Tatwa Sandeepika" by Kaviraja Dr Ambikadutt Shastri, vol-1, EditionReprint-2014, Chapter-06, Nidanasthana Chaukhamba Bharati Academy. Page No.-326,327,

6. WWW.webmd.com/Diabetes.

7. Rasatarangini; Tarangini Hindi Commentary, Tikakar Dr. Devanath Singh Gautam; 22nd Tarang, Page No.558-567

8. Ayurveda Prakasha Written by; Shrigulraja Sharma Chaukhamba Bharati Academy, Chapter-04 Page No.427-434

9. A textbook of Rasasastra by Ravindra Angadi Chaukhamba Bharati Academy, Chapter-15, Page No-203211

10. https://en.wikipedia.org/wiki/Diabetes mellitus

\section{Source of Support: Nil Conflict of Interest: None Declared}

How to cite this URL: Esha Dhiman et al: A Clinical Study of Shilajeet Vati In Prameha Purvarupa (Pre-Diabetic State). International Ayurvedic Medical Journal \{online\} 2021 \{cited November 2021\} Available from: http://www.iamj.in/posts/images/upload/2665_2670.pdf 